\title{
Enhancing Catalyst Efficiency of Activated Carbon for Oxygen Reduction Reaction in Air Cathode Microbial Fuel Cell Application Jean Pierre Muhoza ${ }^{1,2 *}$, Hongzhi Ma, ${ }^{2}$, Loissi Kalakodio ${ }^{1,3}$ and Dzivaidzo Mumbengegwi ${ }^{1}$
}

${ }^{1}$ Department of Environmental Engineering, University of Science and Technology Beijing, 30 Xueyuan Road, Haidian District, Beijing, PR China ${ }^{2}$ Eco-Earth Joint Laboratory of Pollution Control and Waste Recycle, University of Science and Technology Beijing, 30 Xueyuan Road, Haidian District, Beijing, PR China ${ }^{3}$ Beijing Key Laboratory of Resource-Oriented Treatment of Industrial Pollutants, Xueyuan 30, Beijing, PR China

\begin{abstract}
Microbial fuel cell (MFC) air cathode present a great potential among other configurations due to its simple design, low cost and direct use oxygen from air as terminal electron acceptor which could help to save tremendous energy used for aeration in conventional wastewater treatment. However, at the cathode oxygen reduction reaction which is vital to generate high power density is naturally slow, therefore a catalyst is needed to overcome its reaction over-potential. Platinum $(\mathrm{Pt})$ is the standard used catalyst in large number of oxidation reduction reactions whether in basic or acidic electrolytes. But, due to its high cost and limited resources it doesn't make it a sustainable candidate for scaling up of this juvenile technology. Activated carbon was found to be a low cost and environmental friendly Oxygen reduction reaction (ORR) catalyst in microbial fuel cell, but still exhibit lower catalytic behavior in its bare form which results in low power output. In this review we aims at making an overview of different promising technologies currently used to boost Activated carbon catalytic performance toward ORR in MFC air cathode and compare their outcomes in terms of catalytic behavior and MFC power output to the standard Pt and bare activated carbon catalysts. Advantages, disadvantages and bottlenecks of these techniques also will be discussed.
\end{abstract}

Keywords: Microbial fuel cell; Air cathode; Oxygen reduction reaction; Activated carbon; Heteroatoms; Transition metals

\section{Introduction}

Microbial fuel cell (MFC) is a potential environmental friendly bioelectrochemical system as it combines treatment of organic wastes and electric energy generation [1-4]. In MFCs, the electrochemically active microorganisms' biofilm colonizes the anodic surface thus oxidizing organic pollutants producing electrons and protons. Electrons are transferred through an external circuit to the cathode where are received by the terminal electron acceptor while protons migrate through the membrane or solution to the cathode to keep electrical neutrality which creates potential difference $[1,5]$. Several applications of this technology such as hydrogen gas production [6], hydrogen peroxide generation [7], desalination [8-10], remote sensors and monitoring devices [11,12] metal recovery at cathode [13] and robots $[12,14]$ to mention but few, have been studied and left researchers with more innovation ideas in the field. Having electrochemical processes catalyzed by biological processes in addition to some other design parameters such as engineering of microbial biofilm structure, decrypting electron transfer mechanisms, cell/reactor configuration, electrode materials and geometries, substrate concentration, retention time, and optimizing cathode catalysts $[15,16]$ makes this system more sensitive to internal losses and gives it a certain level of complexity $[17,18]$. This and other challenges that are still unanswered are the bottlenecks for MFC application in real environment $[15,19]$. Therefore, current researches focus on limiting factors and ways to curb their effects thus increasing the performance [2,20,21]. Among others, is trying different MFC design configurations where MFC aircathode proved to more advantageous over double chamber for scaling up because of its simple structure, low cost and direct use oxygen in air, which could removes aeration from conventional wastewater treatment process [5,22]. Due to its high reduction potential and inexhaustible source, Oxygen is the most fairly used terminal electron acceptor and is considered to be competent for MFC air-cathode application and scale up as it plays a critical role in both organic oxidation and energy recovery at the cathode [23].
Following the torpid inherent character of the Oxygen Reduction Reaction (ORR), the design of the air-cathode is the single greatest challenge for making an MFC a useful and scalable technology, therefore a chemical catalyst should be used to increase the rate of the reaction [24]. Besides, this reaction is difficult to engineer as the electrons, protons and oxygen must all meet at a catalyst in a tri-phase reaction (solid catalyst, air, and water). Besides being exposed to both air and water, the catalyst must be also on a conductive surface, in order to make electrons and protons reach the same point in these different phases [1].

Platinum (Pt) is a commonly used catalyst however high-cost [24], low availability and poor stability [25] of this noble metal makes it difficult for massive production of cathodes, thus hinder MFCs scale up for practical application [26]. Alternatives to Pt includes inexpensive non-noble metal materials and their oxides such as transition metal Co [21,27], $\mathrm{Fe}_{3} \mathrm{O}_{4}$ [28] and $\mathrm{MnO}_{2}$ [29]. However, these metal ions found to cause secondary pollution as they exhibited potential leaching into solution. Beside, to have the same performance as platinum high loading is needed which ends up increasing the overall cost [5].

With the advantage of easy access at low-price, good catalytic performance, high conductivity, durability and regeneration [20], recently using activated carbon (AC) powder as catalyst in air-cathodes

${ }^{*}$ Corresponding author: Muhoza Jean Pierre, Department of Environmental Engineering, University of Science and Technology Beijing, 30 Xueyuan Road, Haidian District, Beijing 100083, PR China, Tel: +8615101596869; E-mail: beyou50@gmail.com

Received December 07, 2017; Accepted December 20, 2017; Published December 27, 2017

Citation: Muhoza JP, Hongzhi Ma, Kalakodio L, Mumbengegwi D (2017) Enhancing Catalyst Efficiency of Activated Carbon for Oxygen Reduction Reaction in Air Cathode Microbial Fuel Cell Application. Int J Waste Resour 7: 315. doi: 10.4172/2252-5211.1000315

Copyright: ( 2017 Pierre MJ, et al. This is an open-access article distributed unde the terms of the Creative Commons Attribution License, which permits unrestricted use, distribution, and reproduction in any medium, provided the original author and source are credited. 
Citation: Muhoza JP, Hongzhi Ma, Kalakodio L, Mumbengegwi D (2017) Enhancing Catalyst Efficiency of Activated Carbon for Oxygen Reduction Reaction in Air Cathode Microbial Fuel Cell Application. Int J Waste Resour 7: 315. doi: 10.4172/2252-5211.1000315

Page 2 of 7

achieved very good results with the production of power densities in MFCs (Table 1) slightly higher than or similar to those obtained using platinum catalyst [30,31]. For instance, a MFC well fitted with an AC cathode bonded with a polytetrafluoroethylene (PTFE) and the current collected by nickel brought about $1220 \mathrm{mWm}^{-2}$ greater to $1060 \mathrm{mWm}^{-2}$ achieved using a Pt catalyst cathode $\left(0.5 \mathrm{mg}-\mathrm{Pt} \mathrm{cm}^{-2}\right)$ and a Nafion binder [32-48]. Another example is a MFC with the same AC cathode configuration but with a diffusion layer made of polydimethylsiloxane (PDMS) coated cloth which produced $1255-1310 \mathrm{mWm}^{-2}$ comparable to $1295 \mathrm{mWm}^{-2}$ obtained with a benchmarking Pt/C cathode $(0.5 \mathrm{mg}$ $\mathrm{Ptcm}^{-2}$ ) [49]. A catalyst layer made of AC/PTFE supported on stainless steel mesh which collects the current as well was made using a rolling process method. This cathode produced $1086 \mathrm{mWm}^{-2}$ in an MFC with a high surface area $\left(1701 \mathrm{~m}^{2} \mathrm{~g}^{-1}\right) \mathrm{AC}$ and $1355 \mathrm{mWm}^{-2}$ with a lower surface area $\left(576 \mathrm{~m}^{2} \mathrm{~g}^{-1}\right) \mathrm{AC}$ powder [50].

Despite its good ORR catalytic activity, but the power output of MFCs with bare AC catalyst is still low which led researchers to find different ways to enhance it. Various approach of modification of AC like mixing with carbon black [51], heating [52] and using dopants [53] has been attempted to take the performance to the level of practical application. Results showed promising catalytic activity, improved power output, low cost, environmental friendliness, and durability [20].

Herein we are going to take brief look at commonly used methods used to enhance the oxygen reduction reaction's catalytic activity of Activated Carbon for better performance of MFC air cathode application.

\section{Oxygen Reduction Reaction Kinetics on MFC Cathode}

Let's first explore a bit more about oxygen reduction reaction; in aqueous solution at the cathode, oxygen reduction reaction (ORR) is mainly completed by either a direct 4-electron reduction pathway from $\mathrm{O}_{2}$ to $\mathrm{H}_{2} \mathrm{O}$ or an indirect 2-electron reduction pathway from $\mathrm{O}_{2}$ to hydrogen peroxide $\left(\mathrm{H}_{2} \mathrm{O}_{2}\right)$ [54]. However, many intermediate species may be involved depending on the catalyst used, physical chemical characteristics of electrode materials and electrolyte. These makes the mechanism of this electrochemical oxygen reduction reaction a bit complicated as shown in equations below with their respective thermodynamic electrode potential at standard conditions [55]:

Acidic aqueous solution:

$$
\begin{array}{lr}
\mathbf{O}_{2}+4 \boldsymbol{H}^{+}+4 \boldsymbol{e}^{-} \rightarrow \mathrm{H}_{2} \boldsymbol{O} & 1.229 \boldsymbol{V} \\
\mathbf{O}_{2}+2 \boldsymbol{H}^{+}+2 \boldsymbol{e}^{-} \rightarrow \boldsymbol{H}_{2} \boldsymbol{O}_{2} & 0.70 \boldsymbol{V} \\
\mathbf{H}_{2} \boldsymbol{O}_{2}+2 \boldsymbol{H}^{+}+2 \boldsymbol{e}^{-} \rightarrow 2 \boldsymbol{H}_{2} \boldsymbol{O} & 1.76 \boldsymbol{V}
\end{array}
$$

Alkaline aqueous solution:

$$
\begin{array}{lc}
\mathbf{O}_{2}+2 \boldsymbol{H}_{2} \boldsymbol{O}+4 \boldsymbol{e}^{-} \rightarrow 4 \boldsymbol{O H}^{-} & 0.401 \boldsymbol{V} \\
\mathbf{O}_{2}+2 \boldsymbol{H}_{2} \boldsymbol{O}+2 \boldsymbol{e}^{-} \rightarrow \boldsymbol{H O}_{2}^{-}+\boldsymbol{O H} \boldsymbol{H}^{-} & -0.065 \boldsymbol{V} \\
\mathbf{H O}_{2}^{-}+\boldsymbol{H}_{2} \boldsymbol{O}+2 \boldsymbol{e}^{-} \rightarrow 3 \boldsymbol{O H}^{-} & 0.867 \boldsymbol{V}
\end{array}
$$

The fact that with the utilization of half of the reactant (oxygen) amount double amount of electrons is transferred, a 4-electrons transfer pathway is targeted in all researches [56].

Prior to MFC assembly and operation, the Rotating Disk Electrode (RDE) test method is the most efficient tool to evaluate reaction kinetics of ORR. It has advantage of reducing mass transfer limitation to catalyst which allows computing of the limiting current [51]. As shown on

\begin{tabular}{|c|c|c|c|c|}
\hline Dopants & Method & Power Density & $\begin{array}{l}\text { Improvement } \\
\%\end{array}$ & Reference \\
\hline \multicolumn{5}{|c|}{ Heteroatoms } \\
\hline $\mathrm{P}$ & Treatment with $\mathrm{H}_{3} \mathrm{PO}_{4}(1 \mathrm{M})$ at $400^{\circ} \mathrm{C}$ & $1096 \pm 33 \mathrm{~mW} / \mathrm{m}^{2}$ & 55 & [32] \\
\hline $\mathrm{N}$ & Ammonia gas treatment & $2450 \pm 40 \mathrm{mWm}^{-2}$ & 28 & [33] \\
\hline $\mathrm{N}-\mathrm{P}$ & Pyrolysis of cellulose using $(\mathrm{NH} 4)_{3} \mathrm{PO}_{4}$ & $2293 \pm 50 \mathrm{mWm}^{-2}$ & 36 & [34] \\
\hline P-S & Pyrolysis of petroleum coke & $1029.77 \pm 99.53 \mathrm{mWm}^{-2}$ & 23.52 & [35] \\
\hline \multicolumn{5}{|c|}{ Transition Metals/Oxides } \\
\hline $\mathrm{Ag}$ & Electrodeposition & $1080 \pm 60 \mathrm{~mW} \mathrm{~m}^{-2}$ & 69 & [36] \\
\hline $\mathrm{NiCO}_{2} \mathrm{O}_{4}$ & $\mathrm{Co}\left(\mathrm{NO}_{3}\right)_{2} \cdot 6 \mathrm{H}_{2} \mathrm{O}, \mathrm{Ni}\left(\mathrm{NO}_{3}\right)_{2} \cdot 6 \mathrm{H}_{2} \mathrm{O}$ and $\left(\mathrm{NH}_{2}\right)_{2} \mathrm{CO}$ autoclaved then carbonized & $1730 \pm 14 \mathrm{~mW} \mathrm{~m}^{-2}$ & 56 & [37] \\
\hline $\mathrm{Fe}_{3} \mathrm{O}_{4}$ & Adding $\mathrm{NSFe}_{3} \mathrm{O}_{4}$ with ethanol in ultrasonic device & $1430 \mathrm{~mW} / \mathrm{m}^{2}$ & 83.3 & [38] \\
\hline $\mathrm{Co}_{3} \mathrm{O}_{4}$ & Cobalt salt $\left(\mathrm{Co}\left(\mathrm{CH}_{3} \mathrm{COO}\right)_{2} \cdot 4 \mathrm{H}_{2} \mathrm{O}\right)$ autoclaved then carbonized & $1500 \pm 14 \mathrm{mWm}^{-2}$ & 41.36 & [39] \\
\hline $\mathrm{Cu}_{0.92} \mathrm{Co}_{2.08} \mathrm{O}_{4}$ & Rolling $20 \%$ of the $\mathrm{Cu}_{0.92} \mathrm{Co}_{2.0} 8 \mathrm{O}_{4}$ and $\mathrm{AC}$ & $1895 \mathrm{~mW} \mathrm{~m}^{-2}$ & 113 & [40] \\
\hline $\mathrm{Cu}_{2} \mathrm{O}$ & Electrodeposition & $1390 \pm 76 \mathrm{mWm}^{-2}$ & 59 & [41] \\
\hline $\mathrm{MnO}_{2}$ & Electrodeposition & $1554 \mathrm{~mW} \mathrm{~m}^{-2}$ & 50 & {$[29]$} \\
\hline \multicolumn{5}{|c|}{ Heteroatom-Transition Metals } \\
\hline $\mathrm{Fe}-\mathrm{N}$ & $\mathrm{Fe}(\mathrm{III}) \mathrm{Cl}_{3}, \mathrm{EDA}$ and $\mathrm{AC}$ mix in ethanol and pyrolyzed at $800^{\circ} \mathrm{C}$ & $2437 \pm 55 \mathrm{mWm}^{-2}$ & 114 & [42] \\
\hline Co-Fe-N & Hydrothermal-assisted annealing & $1770.8 \pm 15.0 \mathrm{mWm}^{-2}$ & 72 & [43] \\
\hline Co-N & Aniline $+\mathrm{Co}\left(\mathrm{NO}_{3}\right)_{2} \cdot 6 \mathrm{H}_{2} \mathrm{O}$ in $0.5 \mathrm{M} \mathrm{H}_{2} \mathrm{SO}_{4}$ then pyrolysis at $900^{\circ} \mathrm{C}$ & $11.02 \mathrm{~W} / \mathrm{m}^{3}$ & 13.3 & [44] \\
\hline $\mathrm{N}-\mathrm{MoS}_{2}$ & $\begin{array}{l}\text { Ammonium molybdate + thiourea + Pluronic F127 + melamine followed by calcination at } \\
\qquad 900^{\circ} \mathrm{C}\end{array}$ & $0.815 \mathrm{Wm}^{-2}$ & 60 & [45] \\
\hline \multicolumn{5}{|c|}{ Acid and Alkaline Treatment } \\
\hline $\mathrm{H}_{3} \mathrm{PO}_{4}$ & Disperse AC into $1 \mathrm{M} 20 \mathrm{ml}$ of acid and stir for $24 \mathrm{~h}$ & $1546 \pm 43 \mathrm{~mW} \mathrm{~m}^{-2}$ & 115 & {$[46]$} \\
\hline $\mathrm{HNO}_{3}$ & & $768 \pm 15 \mathrm{~mW} \mathrm{~m}^{-2}$ & 57 & \\
\hline
\end{tabular}
figure 1, performance indicators such as onset potential $\left(\mathrm{E}_{\text {onset }}\right)$ the more positive the better [57], half-wave potential $\left(\mathrm{E}_{1 / 2}\right)$, overpotential under a specific current density $\left(\eta_{j}\right)$, and diffusion-limiting current density $\left(\mathrm{j}_{\mathrm{L}}\right)$ (better when it's large) are indicated on an ORR-RDE typical polarization curve.

For both ORR and fuel cells performance, the lower the 


\begin{tabular}{|c|c|c|c|c|}
\hline $\mathrm{HCl}$ & & $1260 \pm 22 \mathrm{~mW} \mathrm{~m}^{-2}$ & 93.7 & \\
\hline $\mathrm{H}_{2} \mathrm{SO}_{4}$ & & $965 \pm 32 \mathrm{~mW} \mathrm{~m}^{-2}$ & 71.7 & \\
\hline $\mathrm{HNO}_{3}$ & Soaking $\mathrm{AC}$ into $5.6 \mathrm{M} \mathrm{HNO}_{3}$ and heating $85^{\circ} \mathrm{C}$ for $6 \mathrm{~h}$ & $537 \pm 36 \mathrm{mWm}^{-2}$ & -67 & [47] \\
\hline $\mathrm{KOH}$ & Soaking $\mathrm{AC}$ into $3 \mathrm{M} \mathrm{KOH}$ and heating $85^{\circ} \mathrm{C}$ for $6 \mathrm{~h}$ & $957 \pm 31 \mathrm{mWm}^{-2}$ & 16 & \\
\hline
\end{tabular}

Table 1: Power output of some MFCs catalyzed by activated carbon modified by different dopants.

overpotential the higher the current density which gives the maximum power density [55].

To analyze ORR catalytic behavior of a given catalyst, the RDE's electrochemical and hydrodynamic properties are correlated with the Koutecký-Levich (K-L) equation 7 below:

$$
\frac{1}{i}=\frac{1}{i_{k}}-\frac{1}{0.62 n F A D_{O_{2}}^{2 / 3} v^{-\frac{1}{6}} C_{O_{2}} \omega^{1 / 2}}
$$

Where $\mathrm{i}$ is the measured current, ik is the kinetic (current the higher the better), $\mathrm{n}$ represent average number of electrons transferred in the reaction, $\mathrm{F}$ is Faraday's constant, $\mathrm{A}$ as the projected surface area of the disk electrode, $\mathrm{DO}_{2}$ the diffusion coefficient of oxygen, $v$ is the kinematic viscosity, $\mathrm{CO}_{2}$ is the concentration of oxygen in solution, and $\omega$ is the rotation rate of the electrode [57]. As it can be seen from Table 2, different doping technics improved the catalytic activities of activated carbon where both onset potentials and current densities were seen to be higher than the control i.e., $\mathrm{Pt} / \mathrm{C}$ or bare $\mathrm{AC}$ catalysts. Also the number of electron transferred (n) is close to four, which is the desired oxygen reduction reaction pathway. This is the result of the remarkable reduction in both ohmic and charge transfer resistances.

\section{Methods for Modification of Activated Carbon Catalyst \\ Heteroatom doping}

One of the key for real applications of MFC technology is using low cost and sustainable materials especially the cathode. Due to its availability and relatively low cost, Activated Carbon has been one of the best alternative catalysts to replace costly Pt as ORR catalyst in MFC [59-62]. However, the power output and catalytic performance of plain AC cathodes was found in need to be improved for the sake of sustainability. All heteroatoms have a greater or lesser attraction for electrons than carbon does. Thus, each bond between a carbon and a heteroatom is polar, therefore, integrating heteroatoms, such as Nitrogen [63,64], Phosphorus [32,65], Sulfur [66], and Boron [67] into the carbon framework has been demonstrated to largely enhance properties like: surface polarity, semi-conducting, fieldemission, mechanical, and electrical behaviors of carbon materials [68]. Heteroatoms breaks electro-neutrality of adjacent carbon atoms, creating complementary charged sites on which oxygen can be absorbed and reduced; thus demonstrating high-efficiency ORR catalytic activities [69]. Methods used to get AC doped with heteroatom include post-treatment of AC with heteroatoms dopants like ammonia [33] or using precursors containing heteroatoms [70] or activating agents for hydrothermal treatment or pyrolysis. Electron-donor properties of activated carbon can be improved by Phosphorus doping leading to an increased ORR catalytic activity as it can be witnessed in a research where MFC was inoculated by domestic wastewater and acetate used as substrate, they used $\mathrm{AC}$ treated with $\mathrm{H}_{3} \mathrm{PO}_{4}(1 \mathrm{M})$ at $400^{\circ} \mathrm{C}$ as ORR catalyst and attained maximum power density of $1096 \pm 33 \mathrm{~mW} / \mathrm{m}^{2}$ which was $55 \%$ higher than the benchmark. This improvement was said to be the result of decreased Ohmic and charge transfer resistance due to the $\mathrm{P}$ atom inserted into AC surface [32]. The same increment was observed by Qin Liu et al. [71] when a P-doped carbon obtained

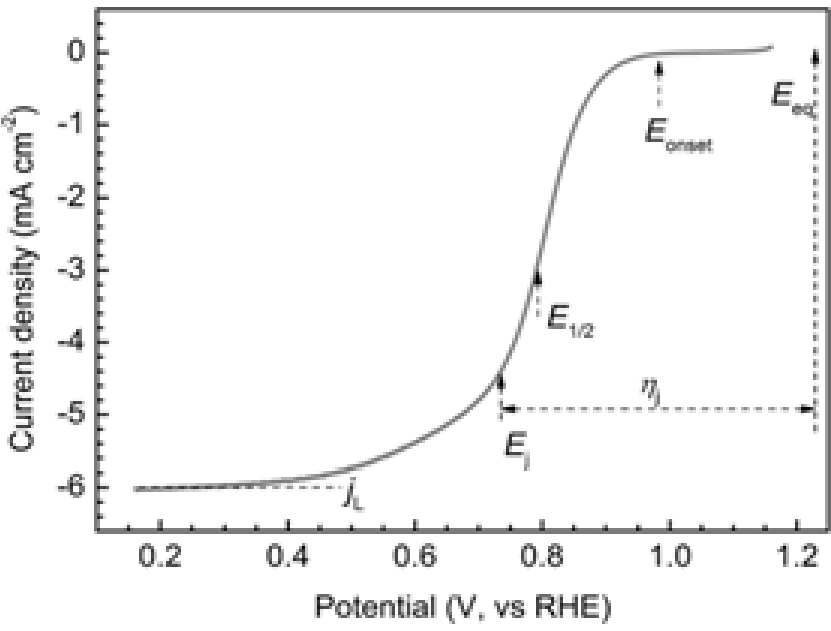

Figure 1: Typical ORR polarization curve of $\mathrm{Pt} / \mathrm{C}$ collected from RDE system with rotating rate of $2000 \mathrm{rpm}$ [58].

\begin{tabular}{|c|c|c|c|c|}
\hline Dopants & $\mathrm{E}_{\text {onset }} / \mathrm{V}$ & Current Density & $\mathbf{n}$ & Reference \\
\hline$P$ & 0.28 & $2.8 \mathrm{~A} / \mathrm{m}^{2}$ & 3.5 & [32] \\
\hline $\mathrm{N}$ & 0.12 & $0.83 \mathrm{~mA} / \mathrm{cm}^{2}$ & 3.9 & [33] \\
\hline $\mathrm{N}-\mathrm{P}$ & 0.11 & $0.54 \mathrm{~mA} / \mathrm{cm}^{2}$ & 3.8 & [34] \\
\hline P-S & 0.2 & $0.936 \mathrm{~mA} / \mathrm{m}^{2}$ & 3.6 & [35] \\
\hline $\mathrm{Ag}$ & 0.32 & $2.85 \mathrm{~mA} / \mathrm{cm}^{2}$ & 4 & {$[36]$} \\
\hline $\mathrm{NiCO}_{2} \mathrm{O}_{4}$ & 0.236 & $25.49 \mathrm{~A} / \mathrm{cm}^{2}$ & 3.72 & [37] \\
\hline $\mathrm{Fe}_{3} \mathrm{O}_{4}$ & 0.27 & $8.71 \times 10^{-4} \mathrm{~A} / \mathrm{cm}^{2}$ & 4 & [38] \\
\hline $\mathrm{Co}_{3} \mathrm{O}_{4}$ & 0.28 & $18.865 \times 10^{-4} \mathrm{~A} / \mathrm{cm}^{2}$ & 3.99 & [39] \\
\hline $\mathrm{Cu}_{0.92} \mathrm{Co}_{2.08} \mathrm{O}_{4}$ & - & $7.85 \mathrm{~mA} / \mathrm{cm}^{2}$ & 3.71 & [40] \\
\hline $\mathrm{Cu}_{2} \mathrm{O}$ & - & $1.03 \times 10^{-3} \mathrm{~A} / \mathrm{cm}^{2}$ & - & [41] \\
\hline $\mathrm{MnO}_{2}$ & 0.31 & $0.81 \mathrm{~mA} / \mathrm{cm}^{2}$ & - & [29] \\
\hline $\mathrm{Fe}-\mathrm{N}$ & 0.1 & $0.81 \mathrm{~mA} / \mathrm{cm}^{2}$ & 4 & [42] \\
\hline Co-Fe-N & - & $14.2 \mathrm{~A} \mathrm{~m}^{-2}$ & 3.77 & [43] \\
\hline Co-N & - & $3.81 \mathrm{~mA} / \mathrm{cm}^{2}$ & 3.96 & [44] \\
\hline $\mathrm{N}-\mathrm{MoS}_{2}$ & 0.24 & $0.61 \times 10^{-4} \mathrm{~A} \mathrm{~cm}^{-2}$ & 3.84 & [45] \\
\hline $\mathrm{H}_{3} \mathrm{PO}_{4}$ & - & $15.275 \times 10^{-4} \mathrm{~A} \mathrm{~cm}^{-2}$ & 3.67 & [46] \\
\hline $\mathrm{HCl}$ & - & $12.878 \times 10^{-4} \mathrm{~A} \mathrm{~cm}^{-2}$ & - & [46] \\
\hline $\mathrm{H}_{2} \mathrm{SO}_{4}$ & - & $9.080 \times 10^{-4} \mathrm{~A} \mathrm{~cm}^{-2}$ & - & [46] \\
\hline $\mathrm{HNO}_{3}$ & - & $7.519 \times 10^{-4} \mathrm{~A} \mathrm{~cm}^{-2}$ & - & {$[46]$} \\
\hline $\mathrm{KOH}$ & - & $4.2 \mathrm{~A} \mathrm{~m}^{-2}$ & 4 & [47] \\
\hline
\end{tabular}

Table 2: Doped activated carbon catalysts performances for ORR.

from cellulose phosphate and prepared at $1000^{\circ} \mathrm{C}$ was used in air cathode producing $1312 \pm 82 \mathrm{mWm}^{-2}$ maximum power density which was claimed to be three times as that with P-free carbon catalyst and higher than the air-cathode with $\mathrm{Pt} / \mathrm{C}$ catalyst. Boron-doped carbon also shows great potential as ORR catalysts following the fact that it has a lower electronegativity than carbon, and the positively polarized boron atoms attract the negatively charged oxygen atoms leading to chemisorption. Besides boron sites can also act as electron donors for the reduction reaction, as the electron density of the graphitic $\pi$-electron system can be transferred to the free $\mathrm{pz}$ orbital of the boron 
[69]. Among other heteroatoms, Nitrogen doping drew more attentions because of its strong electron donor behavior and enhanced $\pi$-bonding which improve the ORR activity and durability [64]. Findings show that during nitrogen doping process four types of structures (Figure 2) are formed through which nitrogen increase ORR catalytic activity of AC [72]. Pyridinic-N and Pyrrolic-N reduces the thermodynamic barriers of ORR, also Graphitic-N (quaternary) enhances the kinetic performance. Through side-on absorption of oxygen molecules, the $\mathrm{O}-\mathrm{O}$ bond is weakened by pyridinic- $\mathrm{N}$ with the lone pair, while electron transfer from the carbon electronic bonds to oxygen antibonding orbitals is enhanced by graphitic-N [73].

One example showed that treatment of commercial activated carbons with ammonia increased nitrogen to 1.8 atomic \% but left oxygen reduced by $29-58 \%$ due to decreased amount of acidic oxygen surface functional groups which significantly improved catalytic performance in neutral media as a result of increment of both number of electrons transferred and onset potentials [33]. Zhang et al. [72] made $\mathrm{N}$-doped AC using cyanamide as nitrogen source after $98 \%$ $\mathrm{H}_{2} \mathrm{SO}_{4}$ and $3 \mathrm{M} \mathrm{KOH}$ pretreatment and resulted in a nitrogen content of $8.65 \%$ (atom \%) (in which $5.56 \%$ is pyridinic-N) on its surface. This $\mathrm{N}$-doped AC exhibited prominent catalytic activity compared to the untreated $\mathrm{AC}$ and the commercial $\mathrm{Pt} / \mathrm{C}(10 \% \mathrm{Pt})$ catalysts which was due to pyridinic- $\mathrm{N}$ indicating that pyridinic- $\mathrm{N}$ is the most active site for ORR in the nitrogen-doped AC.

Incorporating two or more heteroatoms into AC surface creates a mutual advantageous conjunction to optimize ORR catalytic behaviors $[34,74,75]$. Following highly porous surface area and increased active sites, an air-cathode MFC with AC based catalyst prepared from petrocoke naturally containing $\mathrm{N}$ and $\mathrm{S}$ reached a power density higher than bare AC [35]. The same results was obtained by Guang et al. [76] and Madhumita et al. [74] which are accredited to the a combined actions of highly efficient active sites coming from a larger number of pyridinic $\mathrm{N}$ and thiophene $\mathrm{S}$ together with the complementary mass-transport properties turning out from the hierarchical porous structure and the high specific surface area. Heteroatoms are a good option, however their incorporation into carbon matrix present another level of complexity to the process, therefore using biomasses natural containing heteroatoms could be a sustainable solution.

\section{Transition metal/oxides doping}

It is relevant to the use of transition metals as electrocatalysts due to their particular properties of forming more than one cationic oxidation state. Besides, these metals can easily change from one oxidation state to another therefore it gives them the ability to tolerate the unchanging reduction and oxidation reactions which take place inside an electrolytic cell, thus improving stability [26,77]. Due to their natural activities, adequate stability in oxidative electrochemical environments, their structural multiplicity, as well as their ability to be mixed, doped, and to be fused with other materials such as carbon and graphene; transition

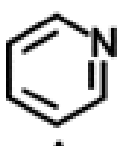

A

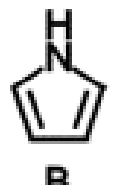

B
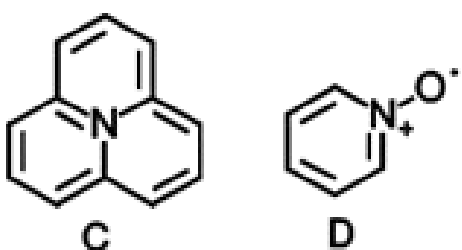

Figure 2: Types of nitrogen bonding in N-doped AC: (a) Pyridinic-N, (b) Pyrrolic-N, (c) Graphitic-N and (d) oxidized nitrogen functional groups. metals and their oxides are regarded as promising way of enhancing AC catalytic activity [26,78]. Various transition metals like cobalt [27,79], manganese [29,77], nickel [80] and iron, have been mostly used as AC dopant for catalysis of oxygen reduction reaction (ORR) among a wide range of these metals.

Doping AC with various transition metals affected its structures and performances differently came up with a structure that look like graphene when they used $\mathrm{Fe}$ and $\mathrm{Mn}$ as dopant while doping with $\mathrm{Co}$, $\mathrm{Ni}$, and $\mathrm{Cu}$ led to a disordered or nanosheet structure where graphenelike structure showed better performance than disordered resulting in the following performance order of their ORR catalytic activity of $\mathrm{Fe}>\mathrm{Co}>\mathrm{Cu}>\mathrm{Mn}>\mathrm{Ni}$. The same array of ORR catalytic activity performance for these metals was observed which is consistent with the order of their active sites contents, fortunately $\mathrm{Fe}$ is the most abundant metal on earth which makes it a good candidate for this application. However, $\mathrm{Fe}$ when used in acidic media suffer from a lower catalytic activity, and from stability issues [26].

Silver was electrodeposited on the activated carbon (AC) air cathode and efficient performance improvement of MFCs was achieved with maximum power density of $1080 \pm 60 \mathrm{mWm}^{-2}, 69 \%$ greater than the plain AC. This made ORR at the cathode to take place via four-electron pathway and the electrodes' total resistance were largely reduced due to the fact that silver has the highest conductivity than any metal [36]. The same method of electrodeposition was used to integrate $\mathrm{MnO}_{2}$ into $\mathrm{AC}$ which left Carnation-like $\mathrm{MnO}_{2}$ crystals bound to the surface of $\mathrm{AC}$ air cathode increasing mesopores thus boosting cathode performance with maximum power density of $1554 \mathrm{mWm}^{-2}$ [29]. Following the same procedure $\mathrm{Cu}_{2} \mathrm{O}$ was added into AC surface which increased mesopore, surface area, charge transfer resistance and total resistance decreased significantly and faster electro-transfer kinetics. High conductivity of $\mathrm{Cu}$ and increased active sites contributed to high ORR catalytic behavior of AC which led to the utmost MFCs' power density using this original air cathode to $1390 \pm 76 \mathrm{mWm}^{-2}$, about $59 \%$ greater than the bare AC air cathode [41].

AC doped with non-stoichiometric nano- $\mathrm{Fe}_{3} \mathrm{O}_{4}$ in air cathode achieved utmost power density improvement by $83 \%$ from $780 \mathrm{~mW} /$ $\mathrm{m}^{2}$ to $1430 \mathrm{~mW} / \mathrm{m}^{2}$ compared with bald air cathode. This was a result of boosted charge transfer that led to the oxygen reduction mechanism through 4-electron pathway [38]. The same trend has been observed when ortho-hexagon spinel nano- $\mathrm{Co}_{3} \mathrm{O}_{4}$ was inserted into $\mathrm{AC}$ at $10 \%$ ration. Significant reduction of the total resistance was observed and a large number of active sites were brought in by higher micropore surface area leading to higher activity for ORR. As a result, the ultimate power density of $1500 \pm 14 \mathrm{mWm}^{-2}$ was produced which was said to be $97.36 \%$ and $41.24 \%$ greater than the air cathode with the plain AC and commercial $\mathrm{Co}_{3} \mathrm{O}_{4}$ respectively [39].

Following a mutually advantageous conjunction for the improvement of activity towards the oxygen reduction reaction and due to the lowering of charger transfer, activation barrier, and higher exchange current density; researchers took into consideration of adding more than one different metal into AC lattice [81]. The air cathode with activated carbon (AC) catalyst doped with $\mathrm{Cu}_{0.92} \mathrm{Co}_{2} .0_{8} \mathrm{O}_{4}$ and calcinated at $600^{\circ} \mathrm{C}$ achieved utmost power density of $1895 \mathrm{~mW} \mathrm{~m}^{-2}$ which was $113 \%$ greater than the benchmark cathode following remarkable decrease of total and charge transfer resistances [40]. This positively correlates with results obtained when air cathode made of AC modified with nano urchin-like $\mathrm{NiCo}_{2} \mathrm{O}_{4}$ using hydrothermal method attaining power density of $1730 \pm 14 \mathrm{mWm}^{-2}$ comparable to $\mathrm{Pt} / \mathrm{C}$ cathode [82]. 


\section{Heteroatom-transition metals co-doping}

Both heteroatom doped AC and Transition metals doped AC have shown increased ORR catalytic activity which makes them a promising alternative for Pt based cathode in MFC. Nevertheless, following results from various researches, combined heteroatom and transition metals $[81,82]$ onto AC surface exhibited much better performance as a result of advantageous combined action the of both dopants which create massive available active sites [42]. This brings in voluminous surface area, improved mass transport, leading to less total resistance and fast electron transport thus facilitate ORR activity of the electrocatalysts [45]. Co and Fe coupled with N into AC enhanced ORR catalytic activity which was ascribed by the author to fast electron transport due to the reduced total resistance and an extended surface area which resulted in an increased performance of MFC [43]. Among other combinations, Iron-Nitrogen $[28,42,83]$ AC doping has been mostly studied and showed better catalytic advantageous combined effect toward ORR reaction directly correlated to the good coordination of both atoms on the surface of AC. Maximum power density of $2437 \pm 55 \mathrm{mWm}^{-2}$ was obtained in MFC with $\mathrm{Fe}-\mathrm{N}-\mathrm{C}$ air-cathode prepared with commercial AC which was $114 \%$ higher than the bare AC. This is a result of increased conductivity due to $\mathrm{Fe}$ atom and mainly to the increase Fe-N bonding particulary Fe-N4 which enlarge numbers of specific reactive sites. Catalyst performance correlate with surface composition as the increase in amount of nitrogen and especially, $\mathrm{N}$ coordinated to metal and pyridinic and pyrrolic types results in increased power density while graphitic nitrogen resulted in worse performance [42]. Similar outcomes were obtained in another study with the synergism of $\mathrm{Cu}$ and $\mathrm{N}$ dopants in AC catalyst making it to possess excellent ORR catalytic activity. Showing better half-wave potential and both the limited current density and onset potential nearly similar to $\mathrm{Pt} / \mathrm{C}$ catalyst is the outcome of the hierarchical structure and large number of pyridinic $\mathrm{N}$ content in addition to high conductivity induced by $\mathrm{Cu}$. Pyridinic-N plays an important role as $\mathrm{O}_{2}$ molecules can easily adsorb on the carbon atoms next to them, because these carbon atoms serve as the active sites for ORR.

\section{Acid and alkaline treatment}

Acid and Alkaline treatment has been considered as a simple and effective way to enhance ORR catalyst activity of AC resulting in better MFC performance. Despite low numbers of published results, this approach found interest and some studies have been done revealing that different nature and concentrations of acids and bases pose different effects on chemical and physical properties of activated carbon. As it can be seen in a study conducted by Zhong Wang et al. [46], they treated $\mathrm{AC}$ using four common acids; i.e., $\mathrm{H}_{3} \mathrm{PO}_{4}, \mathrm{HCl}$, $\mathrm{H}_{2} \mathrm{SO}_{4}$ and $\mathrm{HNO}_{3}$ and found out that $\mathrm{AC}$ treated with $1 \mathrm{M}$ acids had increased ORR catalytic activity followed an order as $\mathrm{AC}-\mathrm{H}_{3} \mathrm{PO}_{4}>\mathrm{AC}$ $\mathrm{HCl}>\mathrm{AC}-\mathrm{H}_{2} \mathrm{SO}_{4}>\mathrm{AC}-\mathrm{HNO}_{3}>\mathrm{AC}$ where $\mathrm{H}_{3} \mathrm{PO}_{4}$ showed an increase in performance of $115 \%$ with the maximum power density of $1546 \pm 43$ $\mathrm{mWm}^{-2}$. The author stated that it was due to a decrease in resistance, enlarged total surface area and degree of graphitization of AC, however too much strong acidic functional group was found to be deleterious to MFC performance. The same adverse effect of high acid concentration treatment of AC was obtained when Wang et al. [47] treated AC with $5.6 \mathrm{M} \mathrm{HNO}_{3}$ which resulted in decrease of power density from $804 \pm 70$ $\mathrm{mWm}^{-2}$ to $537 \pm 36 \mathrm{mWm}^{-2}$, however alkaline $(3 \mathrm{M} \mathrm{KOH})$ pretreatments increased power production by $16 \%$.

\section{Conclusion}

Activated carbon (AC) has been regarded as a potential substitute of costly Platinum as oxygen reduction reaction catalyst in Air cathode Microbial fuel Cell. However, MFCs catalyzed by bare AC showed limited power output which is a critical factor for scaling up and sustainability of this environmental friendly technology. This study shows that, doping with heteroatom, transition metals or their co-doping was found is a good option to enhance the ORR catalytic activity of AC. Among other heteroatoms, Nitrogen doped AC showed better performance than other Heteroatoms because of its strong electron donor behavior and it does so through Pyridinic-N, Pyrrolic-N and Graphitic-N which weaken $\mathrm{O}-\mathrm{O}$ bond and facilitate electron transfer. Throughout a wide range of transition metal Iron $(\mathrm{Fe})$ doped $\mathrm{AC}$ is most favorable as it is abundant and due to its high conductivity, but when used in acidic media suffer from a lower catalytic activity and stability issues as the cathode can easily corrode. Both acidic and alkaline treatment of AC has been used by some researchers and they found out that strong acid are detrimental to AC catalytic activity but moderate acid treatment would increase the total surface area and the degree of graphitization of treated AC, resulting in a better electrocatalytic activity; however due to limited literature alkaline treatment effects are not well known. Heteroatoms and transition metals co-doping wins over other technics as a result of synergic effect brought in by two or more dopants which creates abundant accessible active sites for oxygen reduction, large surface area, improved mass transport leading to less total resistance and fast electron transport thus enhance ORR activity of activated carbon. Though these systems seem promising, however their not only bring another level of complexity and cost to the MFC construction and operation but also the reaction mechanisms are not fully understood which hampers the scale up of the technology. Therefore, more attention should be paid to the use of biomasses naturally containing heteroatoms and transition metals to prepare Activated carbon. Also there should be an increased effort in deciphering mechanisms of oxygen reduction reaction in different settings.

\section{References}

1. Logan BE (2008) Microbial Fuel Cells. John Wiley \& Sons, Inc, New Jersey.

2. Venkata Mohan S, Velvizhi G, Modestra A, Sandipam S (2014) Microbial fue cell: Critical factors regulating bio-catalyzed electrochemical process and recent advancements. Renew Sust Energ Rev 40: 779-797.

3. Khan MD, et al. (2017) Bioelectrochemical conversion of waste to energy using microbial fuel cell technology. Process Biochem 57: 141-158.

4. Wang H, Park JD, Ren ZJ (2015) Practical energy harvesting for microbial fue cells: a review. Environ Sci Technol 49: 3267-77.

5. Wang Z, Mahadevanb GD, Wu Y, Zhao F (2017) Progress of air-breathing cathode in microbial fuel cells. J Power Sources 356: 245-255.

6. Logan BE, Call D, Cheng S, Hamelers HV, Sleutels TH (2008) Microbia electrolysis cells for high yield hydrogen gas production from organic matter Environ Sci Technol 42: 8630-8640

7. Dong $\mathrm{H}$, Liu $\mathrm{X}, \mathrm{Xu} \mathrm{T}$, Wang $\mathrm{Q}$, Chen $\mathrm{X}$, et al. (2018) Hydrogen peroxide generation in microbial fuel cells using graphene-based air-cathodes. Bioresour Technol 247: 684-689.

8. Meng F, Jiang J, Zhao Q, Wang K, Zhang Q, et al. (2014) Bioelectrochemical desalination and electricity generation in microbial desalination cell with dewatered sludge as fuel. Bioresour Technol 157: 120-126.

9. Kokabian B, Smith R, Brooks JP, Gude VJ (2017) Bioelectricity production in photosynthetic microbial desalination cells under different flow configurations. $J$ Ind Eng Chem.

10. Borjas ZA, Esteve-Núñez, Ortiz JM (2017) Strategies for merging microbia fuel cell technologies in water desalination processes: Start-up protocol and desalination efficiency assessment. J Power Sources 356: 519-528.

11. Juan J, Guzman KGC, Marcus O Gaya, Sage E, Radachowskya, et al. (2010) Benthic mfcs for long term power sources. in SPIE Defense, Security and Sensing. 
12. Stuart W (2000) "Gastrobots"-Benefits and Challenges of Microbial Fuel Cells in FoodPowered Robot Applications. Auton Robots 9: 99-111.

13. Rodenas Motos P, Molina G, Heijne AT, Buisman C (2017) Prototype of a scaled-up microbial fuel cell for copper recovery. J Chem Technol Biotechno 92: $2817-2824$

14. Ioannis leropoulos CM, John Greenman, lan Horsfield, John Hart (2004) Energy autonomy in robots through Microbial Fuel Cells.

15. Santoro C, Arbizzani C, Erable E, leropoulos I (2017) Microbial fuel cells: From fundamentals to applications. A review. J Power Sources 356: 225-244.

16. Logan BE (2010) Scaling up microbial fuel cells and other bioelectrochemical systems. Appl Microbiol Biotechnol 85: 1665-1671.

17. Giuliano C, Premiera JRK, lain Michieb, Arseniy Popovb, Hitesh Boghania, et al. (2016) Issues of scale in microbial fuel cells and bioelectrochemical systems Renewable Energy Society (CRES) Annual Conference.

18. Logan BE, Hamelers B, Rozendal R, Schorder U, Keller J, et al. (2006) Microbial fuel cells $\square$ methodology and technology. Environ Sci Technol 40: 5181-5192.

19. Dong H, Yu H, Wang X (2012) Catalysis kinetics and porous analysis of rolling activated carbon-PTFE air-cathode in microbial fuel cells. Environ Sci Technol 46: $13009-13015$

20. Zhang E, Wang F, Yu Q, Scott K, Wang X, et al. (2017) Durability and regeneration of activated carbon air-cathodes in long-term operated microbial fuel cells. J Power Sources 360: 21-27.

21. Kumar RL, Singh L, Zularisam AW (2017) Enhanced oxygen reduction reaction in air-cathode microbial fuel cells using flower-like $\mathrm{Co}_{3} \mathrm{O}_{4}$ as an efficient cathode catalyst. International Int J Hydrogen Energy 30: 19287-19295.

22. Du Z, Li H, Gu T (2007) A state of the art review on microbial fuel cells: A promising technology for wastewater treatment and bioenergy. Biotechnol Adv 25: 464-82.

23. Vishwanathan AS, Sai SS, Rao G (2015) The oxygen paradox in microbial fuel cells. Curr Scien 109: 1390-1391.

24. Trapero JR, Horcajada L, Linares JJ, Lobato J (2017) Is microbial fuel cell technology ready? An economic answer towards industrial commercialization. Appl Energy 185: 698-707.

25. Zhu Y, Zhou W, Chen Y, Yu J, Xu X, et al. (2015) Boosting Oxygen Reduction Reaction Activity of Palladium by Stabilizing Its Unusual Oxidation States in Perovskite. Chem Mater 27: 3048-3054

26. Osgood H, Devaguptapu SV, Xu H, Cho J, Wu G (2016) Transition metal (Fe, $\mathrm{Co}, \mathrm{Ni}$, and $\mathrm{Mn}$ ) oxides for oxygen reduction and evolution bifunctional catalysts in alkaline media. Nano Today 11: 601-625.

27. Huang Q, Zhou P, Yang H, Zhu L, Wu H (2017) CoO nanosheets in situ grown on nitrogen-doped activated carbon as an effective cathodic electrocatalyst for oxygen reduction reaction in microbial fuel cells. Electrochimica Acta 232: 339347

28. Tang $H$, Zang $Y$, Zeng $Y$, Wang $R$, Cai $S$, et al. (2017) Iron-embedded nitrogen doped carbon frameworks as robust catalyst for oxygen reduction reaction in microbial fuel cells. Appl Catal B 202: 550-556

29. Zhang P, Li K, Liu X (2014) Carnation-like MnO2 modified activated carbon air cathode improve power generation in microbial fuel cells. J Power Sources 264: 248-253.

30. Zuo K, Liang S, Liang P, Zhou X, Sun D, et al. (2015) Carbon filtration cathode in microbial fuel cell to enhance wastewater treatment. Bioresou Technol 185: $426-430$

31. Zhang X, He W, Yang W, Liu J, Wang Q, et al. (2016) Diffusion laye characteristics for increasing the performance of activated carbon air cathodes in microbial fuel cells. Environ Sci Water Res Technol 2: 266-273.

32. Chen Z, Li K, Pu L (2014) The performance of phosphorus (P)-doped activated carbon as a catalyst in air-cathode microbial fuel cells. Bioresour Technol 170: $379-84$

33. Watson VJ, Nieto Delgado C, Logan BE (2013) Improvement of activated carbons as oxygen reduction catalysts in neutral solutions by ammonia gas treatment and their performance in microbial fuel cells. J Power Sources 242 $756-761$

34. Liu Q, Zhou Y, Chen S, Zhao F (2015) Cellulose-derived nitrogen and phosphorus dual-doped carbon as high performance oxygen reduction catalyst in microbial fuel cell. J Power Sources 273: 1189-1193.

35. Zhang P, Liu X, Li K, Lu Y (2015) Heteroatom-doped highly porous carbon derived from petroleum coke as efficient cathode catalyst for microbial fuel cells. Int J Hydrogen Energy 40: 13530-13537.

36. Pu L, Li K, Chen Z, Fu Z (2014) Silver electrodeposition on the activated carbon air cathode for performance improvement in microbial fuel cells. J Power Sources 268: 476-481.

37. Ge B, Li K, Fu Z, Kuang K (2016) The performance of nano urchin-like $\mathrm{NiCo} 2 \mathrm{O} 4$ modified activated carbon as air cathode for microbial fuel cell. $J$ Power Sources 303: 325-332.

38. Fu Z, Yan L, Li K, Ge B, Pu L, et al. (2015) The performance and mechanism of modified activated carbon air cathode by non-stoichiometric nano $\mathrm{Fe}_{3} \mathrm{O}_{4}$ in the microbial fuel cell. Biosens Bioelectron 74: 989-995.

39. Ge B, Li K, Fu Z, Pu L, Zhang X (2015) The addition of ortho-hexagon nano spinel $\mathrm{Co} 3 \mathrm{O} 4$ to improve the performance of activated carbon air cathode microbial fuel cell. Bioresour Technol 195: 180-187.

40. Wang J, et al. (2017) Temperature-depended Cu 0.92 Co 2.08 O 4 modified activated carbon air cathode improves power output in microbial fuel cell. International Journal of Hydrogen Energy 42: 3315-3324.

41. Zhang X, Li K, Yan P, Liu Z, Pu L (2015) N-type $\mathrm{Cu}_{2} \mathrm{O}$ doped activated carbon as catalyst for improving power generation of air cathode microbial fuel cells. Bioresour Technol 187: 299-304.

42. Pan Y, Mo X, Li K, Pu L, Liu D, et al. (2016) Iron-nitrogen-activated carbon as cathode catalyst to improve the power generation of single-chamber aircathode microbial fuel cells. Bioresour Technol 206: 285-299.

43. Huang Q, Zhou $P$, Yang $H$, Wu $H$ (2017) In situ generation of inverse spine $\mathrm{CoFe}_{2} \mathrm{O}_{4}$ nanoparticles onto nitrogen-doped activated carbon for an effective cathode electrocatalyst of microbial fuel cells. Chem Eng J 325: 466-473.

44. Tang X, Ng HY (2017) Cobalt and nitrogen-doped carbon catalysts for enhanced oxygen reduction and power production in microbial fuel cells. Electrochimica Acta 247: 193-199.

45. Hao L, Yu J, Xu X, Zou J (2017) Nitrogen-doped MoS2/carbon as highly oxygenpermeable and stable catalysts for oxygen reduction reaction in microbial fue cells. J Power Sources 339: 68-79.

46. Wang Z, et al. (2017) The influence and mechanism of different acid treatment to activated carbon used as air-breathing cathode catalyst of microbial fuel cell. Electrochimica Acta 246: 830-840.

47. Wang X, Gao N, Zhou Q, Dong H, Yu H, et al. (2013) Acidic and alkaline pretreatments of activated carbon and their effects on the performance of aircathodes in microbial fuel cells. Bioresour Technol 144: 632-636.

48. Zhang F, Cheng S, Pant D, Logan BE (2009) Power generation using an activated carbon and metal mesh cathode in a microbial fuel cell. Electrochem commun 11: 2177-2179.

49. Wei B, Tokash JC, Chen G, Hickne MA, Logan BE (2012) Development and evaluation of carbon and binder loading in low-cost activated carbon cathodes for air-cathode microbial fuel cells. Rsc Advances 2: 12751-12758.

50. Zhang X, Xia X, IVAnov I, Huang X, Logan BE (2014) Enhanced activated carbon cathode performance for microbial fuel cell by blending carbon black. Environ Sci Technol 48: 2075-2081

51. Dong H, Yu H, Yu H, Wang X (2013) Enhanced performance of activated carbon-polytetrafluoroethylene air-cathode by avoidance of sintering on catalyst layer in microbial fuel cells. J Power Sources 232: 132-138.

52. Wei T, Zhang Q, Wei X, Gao Y, Li H (2016) A Facile and Low-Cost Route to Heteroatom Doped Porous Carbon Derived from Broussonetia Papyrifera Bark with Excellent Supercapacitance and $\mathrm{CO}_{2}$ Capture Performance. Sci Rep 6: 22646 .

53. Rahimnejad M, Adhami A, Darvari S, Zirepour A, Oh S (2015) Microbial fue cell as new technology for bioelectricity generation: A review. Alexandria Engineering Journal 54: 745-756.

54. Song C, Zhang J (2008) Electrocatalytic oxygen reduction reaction. PEM Fue Cell Electrocatalysts and Catalyst Layers: Fundamentals and Applications.

55. Erable BD, Feron, Bergel A (2012) Microbial catalysis of the oxygen reduction reaction for microbial fuel cells: a review. Chem Sus Chem 5: 975-987. 
Citation: Muhoza JP, Hongzhi Ma, Kalakodio L, Mumbengegwi D (2017) Enhancing Catalyst Efficiency of Activated Carbon for Oxygen Reduction Reaction in Air Cathode Microbial Fuel Cell Application. Int J Waste Resour 7: 315. doi: 10.4172/2252-5211.1000315

56. Watson VJ, Nieto Delgado C, Logan BE (2013) Influence of chemical and physical properties of activated carbon powders on oxygen reduction and microbial fuel cell performance. Environ Sci Technol 47: 6704-6710.

57. Ge X, Sumboja A, Wuu D, An T, Li B, et al. (2015) Oxygen Reduction in Alkaline Media: From Mechanisms to Recent Advances of Catalysts. ACS Catal 5: 4643-4667.

58. Tursun H, Liu R, Li J, Abro R, Wang X, et al. (2016) Carbon Material Optimized Biocathode for Improving Microbial Fuel Cell Performance. Front Microbiol 7: 6.

59. Santoro C, Artyushkova K, Babanova S, Schuler AJ (2014) Parameters characterization and optimization of activated carbon (AC) cathodes for microbial fuel cell application. Bioresour Technol 163: 54-63.

60. Li J, Luo S, He Z (2016) Cathodic fluidized granular activated carbon assistedmembrane bioelectrochemical reactor for wastewater treatment. Separation and Purification Technology 169: 241-246.

61. Shi X, et al. (2012) Application of nitrogen-doped carbon powders as low-cost and durable cathodic catalyst to air-cathode microbial fuel cells. Bioresour Technol 108: 89-93.

62. Antolini E (2016) Nitrogen-doped carbons by sustainable $\mathrm{N}$ - and C-containing natural resources as nonprecious catalysts and catalyst supports for low temperature fuel cells. Renew Sustain Energy Rev 58: 34-51.

63. Liu Z, Peng F, Wang H, Zhu L (2011) Novel phosphorus-doped multiwalled nanotubes with high electrocatalytic activity for $\mathrm{O} 2$ reduction in alkaline medium. Catal Commun 16: 35-38.

64. Yang Z, Yao Z, Li G, Fang G, Nie H, et al. (2011) Sulfur-doped graphene as an efficient metal-free cathode catalyst for oxygen reduction. ACS Nano 6: 205-211.

65. Wang J, Chen Y, Zhang Y, lonescu ML, Li R, et al. (2011) 3D boron doped carbon nanorods/carbon-microfiber hybrid composites: synthesis and applications in a highly stable proton exchange membrane fuel cell. J Mater Chem 21: 18195-18198.

66. Rana MG, Arora G, Gautam UK (2015) N- and S-doped high surface area carbon derived from soya chunks as scalable and efficient electrocatalysts for oxygen reduction. Sci Technol Adv Mater 16: 014803.

67. Paraknowitsch JP, Thomas A (2013) Doping carbons beyond nitrogen: an overview of advanced heteroatom doped carbons with boron, sulphur and phosphorus for energy applications. Energy Environ Sci 6: 2839.

68. Lu Y, Zhu N, Yin F, Yang T, Wu P, et al. (2017) Biomass-derived heteroatomsdoped mesoporous carbon for efficient oxygen reduction in microbial fuel cells. Biosens Bioelectron 98: 350-356.

69. Liu Q, Chen S, Zhou Y, Zhao F (2014) Phosphorus-doped carbon derived from cellulose phosphate as efficient catalyst for air-cathode in microbial fuel cells. J Power Sources 261: 245-248.

70. Zhang B, Wen Z, Ci S, Mao S, Chen J, et al. (2014) Synthesizing nitrogen- doped activated carbon and probing its active sites for oxygen reduction reaction in microbial fuel cells. ACS Appl Mater Interfaces 6: 7464-70.

71. Yan L, Yu J, Houston J, Luo H (2017) Biomass derived porous nitrogen doped carbon for electrochemical devices. Green Energy \& Environment 2: 84-99.

72. Sahoo M, Ramaprabhu S (2017) Nitrogen and sulfur co-doped porous carbon - is an efficient electrocatalyst as platinum or a hoax for oxygen reduction reaction in acidic environment PEM fuel cell?. Energy 119: 1075-1083.

73. Han C, Bo X, Zhang Y, Guo L (2014) One-pot synthesis of nitrogen and sulfur co-doped onion-like mesoporous carbon vesicle as an efficient metal-free catalyst for oxygen reduction reaction in alkaline solution. J Power Sources 272: $267-276$.

74. Cheng GC, Guanlan L, Liu C, Yuan L, Chen W, et al. (2017) Efficient Synthesis of Nitrogen- and Sulfur-co-Doped Ketjenblack with a Single-Source Precursor for Enhancing Oxygen Reduction Reaction Activity. Chem 23: 3674-3682.

75. Li X, Hu B, Suib S, Lei Y, Li B (2010) Manganese dioxide as a new cathode catalyst in microbial fuel cells. J Power Sources 195: 2586-2591.

76. Kodali M, Santoro C, Serov AA, Kabir SA, Artyushkova K, et al. (2017) Air Breathing Cathodes for Microbial Fuel Cell using Mn-, Fe-, Co- and $\mathrm{Ni}-$ containing Platinum Group Metal-free Catalysts. Electrochim Acta 231: 115124.

77. Liu Z, Ge B, Li K, Zhang X, Huang K (2016) The excellent performance and mechanism of activated carbon air cathode doped with different type of cobalt for microbial fuel cells. Fuel 176: 173-180.

78. Luo S, He Z (2016) Ni-Coated Carbon Fiber as an Alternative Cathode Electrode Material to Improve Cost Efficiency of Microbial Fuel Cells. Electrochimica Acta 222: 338-346.

79. Bosch-Jimenez P, Martinez-Crespiera S, Amantia D, Borràs Camps E, Forns I, et al. (2017) Non-precious metal doped carbon nanofiber air-cathode for Microbial Fuel Cells application: Oxygen reduction reaction characterization and long-term validation. Electrochimica Acta 228: 380-388.

80. Ge B, Li K, Fu Z, Pu L, Zhang X, et al. (2016) The performance of nano urchinlike NiCo 204 modified activated carbon as air cathode for microbial fuel cell. J Power Sources 303: 325-332.

81. Rojas-Carbonell S, Santoro C, Serov A, Atanassov P (2017) Transition metalnitrogen-carbon catalysts for oxygen reduction reaction in neutral electrolyte. Electrochem commun 75: 38-42.

82. Santoro C, Serov A, Gokhale R, Rojas-Carbonell S, Stariha L, et al. (2017) A family of Fe-N-C oxygen reduction electrocatalysts for microbial fuel cell (MFC) application: Relationships between surface chemistry and performances. Appl Catal B 205: 24-33.

83. Yu H, Fisher A, Cheng D, Cao D (2016) Cu,N-codoped Hierarchical Porous Carbons as Electrocatalysts for Oxygen Reduction Reaction. ACS Appl Mater Interfaces 83: 21431-21439. 